\title{
CONSEQUENNCIAS DA QUEBRA DA CONFIANÇA NAS RELAÇÕES AMOROSAS COM CONTÁGIO DO VÍRUS HIV: DOS DANOS MORAL E MATERIAL ${ }^{1}$
}

CONSEQUENCES OF BREACH OF TRUST IN LOVING RELATIONSHIPS WITH HIV VIRUS

CONTACTS: MORAL AND MATERIAL DAMAGE

Cláudia Gil MENDONÇA ${ }^{2}$

Lislene Ledier AYLON $^{3}$

ISSUE DOI: 10.21207/2675-0104.2019.925

\section{RESUMO}

O presente artigo trata sobre a responsabilização civil daquele que, possuindo uma relação amorosa tida como de caráter sério, buscou fora dessa, relações sexuais e destas, levou para dentro de seu

\footnotetext{
${ }^{1} \mathrm{O}$ presente artigo sintetiza a monografia de conclusão da pesquisa, realizada para o Programa Interno de Bolsas de Iniciação Científica (PIBIC 2018-2019) da Faculdade de Direito de Franca (FDF), Franca/SP.

${ }^{2}$ Discente da Faculdade de Direito de Franca (FDF), Franca/SP. Bolsista do Programa Interno de Bolsas de Iniciação Científica (PIBIC 2018-2019).

${ }^{3}$ Doutoranda no programa de Doutorado em Direito, da FADISP (Faculdade Autônoma de Direito) em São Paulo/SP, tendo concluído os créditos em dezembro de 2017. Mestre em Direito Privado pela Universidade de Franca (2002). Pós Graduada em Direito Penal e Processual Penal pela Faculdade de Direito de Franca (1995).Graduada em Direito pela Universidade Estadual Paulista Júlio de Mesquita Filho (1989), Foi professora de Direito Civil na UNIFRAN (Universidade de Franca) de1999 a 2005, na UNIP (Universidade Paulista), campus de Santos/SP de 2013 a 2016 e na UNAERP (Universidade de Ribeirão Preto), campus Guarujá/SP, de 2014 a 2016. Atuou como avaliadora em bancas de defesa de monografias em cursos de Pós-Graduaçao lato sensu da UNOPAR (universidade do Norte do Paraná em 2016 e 2017. Atualmente é professora na Faculdade de Direito de Franca/SP, da disciplina Direito Civil III (Contratos) e coordenadora do Núcleo de Assistência Judiciária da Faculdade de Direito de Franca.
} 
relacionamento o vírus HIV. Aqui, tem-se a confiança quebrada duas vezes: a primeira no ato da traição e a segunda, no ato da contaminação do vírus. Objetiva-se impor uma responsabilização àquele que antes compartilhava consigo pilares familiares, em razão do preconceito que traz consigo o vírus, visando a amenização da transgressão da dignidade pela segurança do ordenamento jurídico.

Palavras - chave: Relações amorosas. Traição. HIV. Responsabilização.

\section{ABSTRACT}

The present article deals with the civil responsability of the one who, having a serious amourus relationship considered serious, sought outside of this, sexual relations and of these, took the HIV virus into his relationship. Here the trust is broken twice: the first in the act of betrayal and the second in the act of virus contamination. The objective is to impose an accountability on those who previously shared family pillars with them, due to the prejudice that the virus brings with it, aiming at softening the transgression of dignity for the security of the legal system.

Keywords: Amourus relationship. Betrayal. HIV. Responsability.

O presente artigo tem por tema exclusivamente um assunto subjetivo, onde a preocupação é voltada para a manutenção da dignidade humana em seu estado total, ou ao menos, em maior parte.

Partindo da ideia de que, uma pessoa possua uma relação amorosa tida como de caráter sério, visando haver pilares para se formar uma unidade familiar, buscam fora dessa, relações sexuais, e como consequência dessas, acabam por introduzir dentro de seus relacionamentos o vírus HIV.

Aqui, falamos da quebra do pilar "confiança", não apenas uma vez, mas duas: ao trair e ao transmitir ao seu parceiro(a), o vírus, muitas vezes letal.

$\mathrm{Na}$ esfera jurídica, essas consequências referem-se à responsabilidade civil de um para com o outro: o dever de indenizar um dano material e principalmente, moral àquele que se dedicou a quem estava a seu lado; material, por tratar-se de possíveis perdas monetárias em razão de tratamento médico e moral pela dignidade e saúde feridas.

É de suma importância ressaltar, que a sociedade atual ainda é eivada de muito preconceito frente aos portadores do vírus HIV, coibindoos e impedindo-os de ter uma vida normal, como trabalhar, frequentar lugares públicos, convivendo assim, com pessoas que não o possuem. $\mathrm{O}$ preconceito ainda se faz muito presente nesses casos, sendo muito comum o receio de um simples aperto de mãos. 
Assim, se faz necessário a imposição de um possível dano moral e/ou material para, ao menos, tentar amenizar as dores sofridas por aqueles que jamais imaginou passar por situações das mais humilhantes possíveis.

Se faz, nesse sentido, a busca pela responsabilização daquele que, de alguma forma feriu de maneira incalculável a dignidade de outrem.

Evidente que se torne impossível mensurar o estrago psicológico de uma traição, ainda mais quando dela provém um vírus, até o presente momento, incurável e, muitas vezes letal.

Portanto, é necessário se fazer busca para, ao menos, minimizar os prejuízos causados e de alguma maneira manter a dignidade daquele que a teve transgredida. Ao adentrarmos na questão em si, se faz necessário, uma breve explicação de família, onde, com certeza foi o primeiro agrupamento humano a se compor de maneira informal e espontânea, o que se faz ainda nos dias atuais.

\section{DA FAMÍLIA}

A história da humanidade retrata nos períodos de descobertas, guerras, a escassez de mulheres, fazendo com que o homem buscasse em outros grupos, relacionar-se sexualmente com outras mulheres. No entanto, foram surgindo as relações individuais, que culminaram nas chamadas relações monogâmicas.

O núcleo familiar, agora dispunha de perfil hierarquizado e patriarcal. Segundo a renomada professora Eva Maria Lakatos ${ }^{4}$, Murdock entende que a família é "um grupo social caracterizado pela residência comum, com cooperação econômica e reprodução".

Esse perfil não resistiu à Revolução Industrial, fazendo assim com que a estrutura familiar mudasse, acabando com o caráter primário de reprodução, migrando-se do campo para as cidades, passando a conviver em espaços menores, aproximando seus membros e prestigiando mais o vínculo afetivo.

Já no entender de Maria Berenice Dias 5 , "LAR - Lugar de Afeto e Respeito", assim é a família formada a partir dos laços de carinho e os atuais pilares de uma relação: amor, respeito, fidelidade e confiança.

\footnotetext{
${ }^{4}$ LAKATOS, Eva Maria. Sociologia geral. 6.ed. São Paulo: Atlas, 1990.

5 DIAS, Maria Berenice. Manual de direito das famílias. 11ed. São Paulo: Revista dos Tribunais, 2016.
} 
Findo o afeto, está ruído o alicerce da família.

A função mais significativa do Estado é organizar a vida em sociedade, de forma que seus membros fiquem sempre amparados, evitando excessos e conflitos de interesses entre eles.

Quando se trata de afetividade, a discussão é sempre muito delicada e o comportamento interior se reflete no exterior; por isso que o chamado "Direito das Famílias" deve sempre refletir as questões atuais de cada país.

Falar de família remete ao modelo convencional: mãe, pai e filhos. No entanto, o mundo vive constantes mudanças; e é nesse oceano de mudanças que acaba por refletir nas relações familiares, alternando, assim, o modelo convencional para uma infinidade de outros modelos.

Nos dias atuais, não é possível conceituar família em relação aos seus membros; mas sim por sentimentos, ou seja, todos aqueles que se uniram através de laços afetivos. Assim, forma-se uma unidade que pode ser chamada, a partir de então, de família. Surge nesse contexto vários tipos de família, tais como matrimonial; informal; homoafetiva; paralela ou simultânea; poliafetiva; monoparental; parental ou anaparental; composta, pluriparental ou mosaico; natural, extensa ou ampliada; substituta; e eudemonista.

O afeto é o cerne de toda relação familiar por meio da qual se alcança a felicidade e a realização completa do grupo social. A essência de família: dar e receber carinho.

No entanto, nos atemos aqui à relação conjugal, às uniões homoafetivas, com certa duração, uma vez que essas constam com o pilar de caráter sério, sem envolver os frutos destas.

O Código Civil de 1916, assim como os Códigos do século XIX, nas normas dedicadas a regulamentar as famílias, trazia em seu bojo, que sua única forma de constituição familiar era o casamento, ou seja, o reflexo da sociedade da época, patriarcal e marcada por institutos jurídicos que pouco mudaram desde a Antiguidade.

O mundo foi se transformando e, com ele, a família teve uma evolução que culminou em sucessivas mudanças legislativas. A mais significativa, até então, era o Estatuto da Mulher Casada (Lei n. 4.121, de 27 de agosto de 1962) que, devolveu a capacidade à mulher casada e conferiu-lhe a garantia a propriedade exclusiva dos bens conquistados com fruto de seu trabalho.

A instituição do divórcio (EC n. 9, de 28 de junho de 1977 e Lei n. 6.515 , de 26 de dezembro de 1977) extinguiu a indissolubilidade do 
matrimônio. Depois disso, veio a Constituição Federal, em 5 de outubro de 1988, e fixou a igualdade entre homens e mulheres, protegendo de forma igualitária todos seus integrantes, sendo um dos maiores avanços no direito brasileiro.

O Código Civil de 2002 buscou amodernar as questões do Direito das Famílias, apesar de ter mantido a estrutura do Código anterior. Incorporou boa parte das alterações legislativas, mas não foi audaz em avançar nem mesmo em direção aos assuntos constitucionalmente legitimados. Quiçá, o notável ganho tenha sido a eliminação das expressões e definições que eram inadequadas e não mais podiam versar com a nova estrutura jurídica e sociedade moderna.

O Direito das Famílias está regulamentado pelo Código Civil, portanto, sua natureza jurídica é o direito privado. Porém, conta com normas de interesse de ordem pública, devido ao compromisso do Estado em proteger a família e organizar as relações de seus indivíduos.

Exemplo disso é a Emenda Constitucional n. 66, de 13 de julho de 2010 que, simplificou a dissolução do casamento, retirando a necessidade de prazo de separação judicial, eliminando qualquer ressalva para a concessão do divórcio.

As pessoas são iguais em direitos, deveres e sentimentos. Amamse igualmente e, portanto, as uniões provenientes do afeto devem ter igual peso na proteção estatal.

No que se refere ao direito subjetivo da família, esse é a colocação de uma pessoa face à determinada norma de direito objetivo (conjunto de normas gerais e abstratas que buscam ordenar a vida social). Se esta colocação for vantajosa, torna-se o indivíduo, titular do direito. Se for desvantajosa, leva-se este a um dever jurídico.

Já os princípios constitucionais da família representam o direcionamento da hermenêutica jurídica, dirigindo o trabalho do intérprete de acordo com os valores e interesses por eles protegidos. É no Direito das Famílias que mais se refletem os princípios que a Constituição Federal promove como valores sociais e essenciais.

Existem princípios gerais, como a dignidade humana, que são sempre predominantes, e princípios especiais que são próprios das relações familiares e devem servir de norte na hora de se analisar qualquer caso que envolva questões de família; exemplo disso é o princípio da afetividade.

Assim podemos destacar da seguinte maneira:

Dignidade da pessoa humana: é o princípio mor, vital ao Estado Democrático de Direito, constando na Constituição Federal logo em seu 
primeiro artigo. É o valor elementar da ordem constitucional devido à preocupação do constituinte com a ascensão dos direitos humanos e da justiça social. É o mais universal de todos. É deste princípio que se defletem todos os demais.

Nas palavras de Daniel Sarmento ${ }^{6}$, a dignidade humana representa o ponto nuclear axiológico da ordem constitucional, disseminando efeitos sobre todo o ordenamento jurídico e medindo não apenas os atos estatais, mas toda a imensidade de relações privadas que se desenvolvem no cerne da sociedade.

Solidariedade familiar: solidariedade é o que cada pessoa deve a outra; reciprocidade. O princípio provém dos vínculos afetivos, trazendo em si forte conteúdo ético. Ensina a professora Maria Berenice Dias ${ }^{7}$, "a pessoa só existe enquanto coexiste".

Igualdade e contenção do retrocesso social: a lei deve considerar todos igualmente, mas deve observar as desigualdades para que estas sejam ponderadas para ressaltar a igualdade material. No âmbito da família, a igualdade atingiu os homens e as mulheres, onde ambos contam com as mesmas obrigações e, também, os filhos, onde não há diferenciação de direitos e obrigações entre os nascidos dentro da relação, fora dela; de sangue ou por adoção.

Afetividade: é a relação de carinho ou cuidado que uma pessoa tem com alguém íntimo ou caro. É um lado da intimidade que pode se alterar muitas vezes ao longo da vida e tem o dom de adentrar e completar todos os demais aspectos da vida da pessoa. É considerado, atualmente, um valor jurídico, uma vez que atravessa várias relações jurídicas, principalmente no Direito das Famílias. É um elemento fundamental para a interação familiar, mas não é um laço que envolve somente membros da família, tem uma tendência externa que põe humanidade em cada uma delas, compondo a família humana universal.

No entanto, a monogamia não é um princípio estatal de família, mas sim de uma regra restrita à proibição de múltiplas relações matrimonializadas, constituídas sob o assentimento do Estado. Não há como considerar a monogamia como um princípio constitucional, mesmo que a lei censure as inúmeras formas de quem não cumpre com a fidelidade, porque a Constituição Federal não a ampara.

\footnotetext{
${ }^{6}$ SAMENTO, Daniel. A ponderação de interesses na Constituição Federal. Rio de Janeiro: Lúmen Júris, 2003.

${ }^{7}$ DIAS, Maria Berenice. Manual de direito das famílias. 11.ed. São Paulo: Revista dos Tribunais, 2016.
} 
Outro ponto que merece destaque no âmbito familiar, e não menos importante, são os sentimentos ali estampados. Destacamos os mais evidentes dentre de uma relação: Amor - sentimento que predispõe alguém a desejar o bem de outra pessoa. É uma afeição desmedida. Querer agradar sem ter determinado interesse, sem esperar retribuição; Respeito - tratar com reverência ou acatamento; honrar. Dar atenção ou importância a; considerar; Fidelidade - aquele que é digno de fé; leal, honrado. Que não falha; com o qual se pode contar; seguro. É ser probo para com alguém. É o compromisso de não trair o parceiro em uma relação amorosa; Confiança - segurança íntima de procedimento. Certeza interna sobre a integridade de caráter, honestidade, zelo e discrição de alguém. É um conceito que as pessoas inspiram a outras e ter confiança em alguém, é dizê-la digna de credibilidade, capaz de desempenhar a função de guardar seus sentimentos, torná-la próxima, familiar.

No tocante à relação amor/confiança no ordenamento jurídico brasileiro, quem melhor define a família é a "Lei Maria da Penha" (Lei n. 11.340, de 7 de agosto

de 2006) em seu artigo $5^{\circ}$, III: "relação íntima de afeto". Dito isto e em consonância com o visto anteriormente, entende-se que o grupo familiar é formado por pessoas que se predispõem a desejar o bem, a dedicar-se incondicionalmente a outra pessoa.

Entrando no cerne da família, da moral e da ética, a professora Maria Berenice Dias ${ }^{8}$, leciona que "moral são normas estabelecidas e aceitas segundo o consenso individual e coletivo". Está presente desde os primórdios como ser social e, portanto, é fundamental para a sociedade, apesar de seu caráter mais pessoal, isto é, parte de certezas íntimas.

Já a ética, corresponde aos conjuntos de padrões morais preestabelecidos, como os deveres e obrigações da pessoa e da sociedade. As duas têm muito em comum: orientam relações humanas, através de condutas exigidas dos indivíduos para viabilizar a vida em sociedade. Elas variam conforme o tempo e o espaço, mas continuam sendo a base do Direito.

Em relação à família, quando se fala de moral, a história do Direito das Famílias se traduz em exclusões em nome da moral e dos bons costumes. O maior exemplo disto é o não reconhecimento dos filhos tidos fora dos casamentos, como uma tentativa de impedir a quebra do pilar "monogamia".

${ }^{8}$ DIAS, Maria Berenice. Manual de direito das famílias. São Paulo: Revista dos Tribunais, 2016. 11.ed 
A jurisprudência não resiste à tentadora empáfia de condenar aqueles que vivem de forma diferente a aceita pela moral conservadora. Isso é negligenciar o ideal de justiça, esquecer-se da ética.

Nas palavras de Maria Berenice Dias", "a justiça não pode ser nem tímida nem preconceituosa. Precisa encontrar saídas que não gerem enormes distorções".

A finalidade da lei não é petrificar a vida e, sim, acompanhar sua evolução, adaptando-se e a adaptando às novas realidades. Para estar próximo ao objetivo principal de justiça, é preciso pôr a ética acima da moral.

E o que falar, quando surge a quebra de confiança entre as pessoas dentro de uma relação amorosa? Recordemos que o principal pilar de sustentação da família é o afeto. É dele que parte qualquer formação de qualquer modelo de entidade familiar. É dele que se originam todos os outros: amor, respeito, fidelidade e confiança.

$\mathrm{O}$ afeto quando cultivado se transforma em amor que gera $\mathrm{o}$ respeito e a confiança, ou seja, o faz digno de receber de outrem seus reais sentimentos, convicções íntimas e verdades internas. A fidelidade vem abrançando tudo isso. A pessoa que ama, respeita e confia, é leal para com a outra e espera que isso seja recíproco, principalmente dentro de laços amorosos onde há a partilha de tudo, prezando pela busca da felicidade e das realizações pessoais. Quando essa fidelidade é ignorada, quebrando a confiança daquele que muito a depositou em si, gera consequências, muitas das vezes, irreparáveis.

\section{DA TRAIÇÃO}

As traições, dentro de um relacionamento, acontecem e sempre aconteceram desde que foi institucionalizada a monogamia. Inúmeros são os motivos que levam um dos membros do casal, ou, até vezes, ambos, a procurarem no exterior de sua família algo ou alguém que lhe trouxesse outras formas de satisfação pessoal.Aqui não cabe tratar de motivos para tal, mas sim, das formas de trair.

Trair é quebrar a confiança daquele ou daquela que deixou sua família originária para que muito lhe confiar a constituição de uma nova. Trair é quebrar a confiança. É abusar da intimidade construída com alguém

\footnotetext{
${ }^{9}$ Op. cit.
} 
pelas costas deste. Quando se constrói uma relação amorosa, é como se atasse um laço de confiança, respeito e fidelidade e desatar esse laço, caracteriza a traição.

Uma traição vai muito além de contato físico, pode ser mera olhada; tudo depende do sentimento envolvido, do tempo do relacionamento e ainda, a maneira em que se deu essa quebra de confiança.

Há nesse sentido uma gama de possibilidades de traição:

Traição moral: um ser moral é aquele que não contradiz as regras sociais estabelecidas. Sendo assim, a traição moral é toda e qualquer maneira de trair que vá confrontar esses dogmas sociais.

Traição psicológica: a traição vai muito além do físico, ela envolve o emocional também. A traição psicológica é aquela criada no imaginário, com devaneios e fixação da ideia da traição. As traições psicológicas dependem da intensidade em que são idealizadas para que causem consequências.

Traição virtual: apesar de não ter contato físico, pode ter o mesmo peso ou até mais que uma traição física, pois muitas vezes, acontece debaixo do próprio teto. A intensidade varia conforme o sentimento envolvido de quem foi traído e de quem traiu; o tempo de duração do relacionamento e em muitos casos, quem é o famoso "pivô" da traição e acima de tudo, a confiança que havia entre eles.

Traição física: o tipo mais evidente de traição é aquele em que uma pessoa tem relações sexuais com outra que não seja seu parceiro ou parceira, fisicamente. Parte da vontade de satisfazer uma vontade individual que diversas vezes não encontra em seu par, outras por mera idealização do ditado popular "a grama do vizinho sempre é mais verde".

A traição física pode trazer para dentro do relacionamento originário muito sofrimento, dor e até mesmo, resultados físicos como infecções e ou doenças. Estas são conhecidas como DST's (doenças sexualmente transmissíveis) e, dependendo de sua espécie, não há cura, trazendo, portanto, um mal ainda mais devastador que apenas a dor da traição.

\section{DO HIV}

As chamadas DST's (doenças sexualmente transmissíveis) ou ainda, IST's (infecções sexualmente transmissíveis) existem desde os tempos mais remotos. 
Aludidas, muitas vezes, na literatura mundial e até mesmo na Bíblia Sagrada, as também chamadas de doenças venéreas - referência à mitológica deusa grega do amor, Vênus - foram espalhadas entre as pessoas ao longo dos tempos, principalmente entre os jovens sexualmente ativos.

Os exemplos mais tradicionais dessas doenças são: a gonorréia, a sífilis, o cancro mole, a granuloma venéreo e o linfogranuloma inguinal. Hoje, aproxima-se de 30 tipos e as mais faladas são o HPV (papilomavírus), HSV (vírus herpes simples) e o HIV (vírus da imunodeficiência humana).

No final da década de 1970, surgiu o primeiro caso de AIDS Síndrome da Imunodeficiência Adquirida-, até então não definida, em uma médica e pesquisadora

dinamarquesa Margrethe P. Rask que, estava na África pesquisando sobre o Ebola. A doença a deteriorou rapidamente, entretanto, ninguém conseguia entender o que estava havendo até então.

A partir da década de 1980, mais especificamente em 1981, nos Estados Unidos que, os primeiros casos foram reconhecidos devido a grande entrada de pacientes com casos de pneumonia por Pneumocystis carinii e de sarcoma de Kaposi (SK) - um câncer raro que até então, praticamente, só se apresentava em idosos e que costumavam a demorar a piorar.

Os novos enfermos morriam rapidamente após a entrada nos hospitais e, o que chamou atenção dos médicos era que os pacientes eram somente homossexuais masculinos. Por esse motivo, a doença foi batizada, inicialmente, de GRID - gay related disease, ou seja, imunodeficiência relacionada aos gays.

O vírus HIV (Vírus da Imunodeficiência Humana) é um retrovírus humano da subfamília Lentivirus.

Sua transmissão se dá pelo contato sexual, por via parental ou verticalmente, da mãe para o feto, sendo a mais frequente, a via sexual. E não há cura, mas existem remédios que podem conter drasticamente a progressão da doença.

HIV e AIDs não são sinônimos. O primeiro é o vírus e a segunda é uma doença crônica e que pode ser fatal. A AIDs se manifesta quando a pessoa está infectada pelo vírus HIV e então este vai danificando todo seu sistema imunológico, de maneira que o organismo não consiga mais lutar contra os invasores que causam a doença e por isso, o portador da doença fica suscetível a inúmeras outras infecções e doenças oportunistas, um exemplo muito comum é a pneumonia. 
Todos estão sujeitos à infecção pelo HIV, independentemente do gênero, idade, opção, orientação e comportamento sexual. Já a AIDs pode ou não se manifestar. $\mathrm{O}$ que importa é o cuidado para que não seja transmitido para outrem, ainda mais se for alguém querido.

O Código Penal Brasileiro, inspirado no Código Dinamarquês e em lei alemã, em seu artigo 130 prevê crime de perigo de contágio venéreo. Prevê-se multa e até detenção, dependendo da gravidade da situação.

$\mathrm{O}$ crime traduz-se em ato de colocar outra pessoa em risco de contaminação por relação sexual, sabendo que é portador de doença que pode ser passada e mesmo assim, não avisa o parceiro ou parceira.

Qualquer pessoa pode ser o agente transmissor da doença, seja ela homem ou mulher.

Será sujeito ativo aquele que pratica o ato sexual consciente de ser portador de doença venérea e, sujeito passivo, aquele que foi posto em risco. Apenas não haverá crime se o sujeito passivo tinha plena consciência do estado do agente e mesmo assim quis manter relações com estes. Caso contrário, será considerado crime, independentemente se a vítima não sabia, se supunha ou apenas, tenha sido alertado sobre o perigo.

Ao longo dos anos, apesar de ter muitas indagações sobre a doença sido esclarecidas e saber que um simples aperto de mão, não faria com que o vírus fosse transmitido, as pessoas continuavam isolando os portadores. Isso porque o preconceito já havia se espalhado e este só é mudado com a quebra de paradigmas de uma geração ou várias gerações.

Portanto, em pleno século XXI, há, ainda, quem discrimine àqueles que possuem HIV. Assim sendo, quando alguém contrai o vírus, a dor da doença é o de menos, o que dói mais são os olhares julgadores e inquisidores da sociedade que devido a um preconceito sem fundamento, pois hoje já existem explicações para tudo e coquetéis que mantém a pessoa saudável, ainda insistem em ferir a dignidade, de forma a isolá-lo do convívio de todos.

Isolar fere a dignidade humana no mais amplo aspecto, pois restringir alguém do convívio social fere a liberdade das pessoas em se manifestar como ser humano dentro de um grupo. Em ouvir, ser ouvido, ajudar e ser ajudado. Fere a ideia de pertencer. Pertencer a um grupo em que se identifique, a que possa ser. Ser humano individual e coletivamente.

Para tanto, no direito brasileiro, quando há esse quebra de confiança com consequente transmissão de do vírus HIV, toda atividade que acarreta em prejuízo gera responsabilidade ou dever de indenizar. Portanto, vê-se que responsabilidade é a situação em que uma pessoa deve 
arcar com consequências de um ato, fato ou negócio danoso praticado por si em prejuízo de outrem.

\section{DA RESPONSABILIZAÇÃO}

Responsabilidade civil é o dever de indenizar. O dever de indenizar provém de uma conduta humana, seja uma ação ou omissão, voluntária (dolo) ou por negligência, imprudência ou imperícia (culpa), que causou em outra pessoa um dano.

Há que se falar ainda em danos morais, que constituem os danos à personalidade, isto é, uma conduta que tenha lesado os direitos à personalidade, como por exemplo: qualquer lesão à liberdade, à opção sexual, à opção religiosa, entre outros. Qualquer conduta alheia que viole algum destes direitos enseja em dever de indenizar.

O dano moral não requer a determinação de um "valor" para a dor ou sofrimento, mas sim uma maneira de atenuar, em parte, as consequências do prejuízo imaterial. Usa-se a expressão "reparação" e não "ressarcimento", vez que esta, refere-se a "preço".

No dano moral, objetiva-se uma compensação pelos males suportados. Estes males são dores, tristezas, amarguras, sofrimentos, angústias causadas em alguém por conduta alheia. $\mathrm{O}$ dano moral indenizável não pressupõe necessariamente a verificação de sentimentos humanos desagradáveis como dor ou sofrimentos.

A dignidade humana pode ser considerada, assim, um direito constitucional subjetivo - essência de todos os direitos personalíssimos -, e é o ataque a esse direito o que se convencionou a chamar dano moral.

Já os danos materiais ou patrimoniais constituem prejuízos, perdas que atingem o patrimônio corpóreo de uma pessoa natural, jurídica ou ente despersonalizado.

Assim sendo, o que se busca é a responsabilização daquele que traiu e contaminou, por via de indenizatória, visto que, esta é o mínimo que se pode fazer para, ao menos, tentar amenizar o dano sofrido que, na maioria dos casos, é imensurável, devido ao preconceito havido na sociedade para com os portadores de HIV e, mais ainda, a AIDS.

No Brasil, até os dias de hoje, noticiou-se um caso de indenização por danos morais a uma mulher que foi traída e consequentemente infectada por seu parceiro, na constância da união estável. 
Faz-se notar que há mais casos, contudo, não são de conhecimento público, pois quem sofre a lesão tem vergonha de portar a doença devido aos olhares julgadores da sociedade.

\section{CONCLUSÃO}

É através do ordenamento jurídico que se faz possível a amenização da dor humana, e, então, faz-se necessário indenizar em dano moral e material aquele que teve sua dignidade e honra ofendidas, além de seu patrimônio a fim de realizar o tratamento, pois este perdurará pela vida toda.

É direito de todos a busca por sanar suas dores morais e materiais no ordenamento jurídico, que é o responsável pelo encontro com o alvo Justiça. E são em casos como este que pode ser vista a beleza da Justiça, na tentativa de, no mínimo, manter um pouco da saúde, da dignidade e da honra do cidadão.

\section{$7 \quad$ REFERÊNCIAS BIBLIOGRÁFICAS}

ANTUNES, Lucyr Jones; MATOS, Kimble T. F. Imonologia médica. São Paulo: Atheneu, 1992. CAVALIERI FILHO, Sergio. Programa de Responsabilidade Civil. 11ed. São Paulo: Atlas, 2014.

DIAS, MARIA BERENICE. Manual de Direito das Famílias. 11.ed. São Paulo:Revista dos Tribunais, 2016.

FERNANDES, Brenda. O Novo Divórcio (Emenda Constitucional n 66/2010). Direito Net, 2010. Disponível em: <https://www.direitonet.com.br/artigos/exibir/5938/O-Novo-Divorcio-EmendaConstitucional-no-66-2010> Acesso em 26 de agosto de 2018.

FERREIRA, Aurélio Buarque de Holanda. Míni Aurélio: o dicionário da língua portuguesa. 8.ed. Curitiba: Positivo, 2007. verb. Família.

HINRICHSEN, Sylvia Lemos. DIP - Doenças Infecciosas e Parasitárias. Rio de Janeiro: Guanabara Koogan S.A, 2005.

JESUS, Damásio E. de. Direito Penal $3^{\circ}$ Volume - Parte Especial. 10 ed. São Paulo: Saraiva, 1994.

LAKATOS, Eva Maria. Sociologia geral. 6.ed. São Paulo, 1990.

MALUF, Adriana Caldas do Rego Freitas Dabus; MALUF, Carlos Alberto Dabus. Curso de Direito de Família. 3. ed. São Paulo: Saraiva, 2018. 
NABUCO, Cristiano. Psicologia da infidelidade: a traição é muito mais comum do que se imagina. Viva Bem, 2018. Disponível em:

<https://cristianonabuco.blogosfera.uol.com.br/2018/02/28/psicologia-da-infidelidade-a-traicao-emuito-mais-comum-do-que-se-imagina/> Acesso em: 05 de dezembro de 2018.

NORONHA, Magalhães E. Direito Penal. São Paulo: Saraiva, 1961.

OLIVEIRA, Adilson Silva de. A Emenda Constitucional $n^{\circ} 66$ e a Lei do Divórcio. In: Âmbito Jurídico, Rio Grande, XIII, n. 79, ago 2010. Disponível em: <http://www.ambitojuridico.com.br/site/índex.php?n_link=revista_artigos_leitura\&artigo_id=8207> Acesso em 03 de setembro de 2018.

ROCHA, Ruth. Minidicionário da língua portuguesa. São Paulo: Scipione, 2009.

RODRIGUES, Silvio. Direito Civil: responsabilidade civil. 19 ed. São Paulo: Saraiva, 2002.

SANCHES JÚNIOR, Amauri Nolasco. A Moral Líquida: um outro lado da traição. Obvious. 2015. Disponível em: <http://obviousmag.org/cultura_liquida/2015/a-moral-liquida-um-outro-lado-datraicao.html> Acesso em: 04 de dezembro de 2018.

SARMENTO, Daniel. A ponderação de interesses na Constituição Federal. Rio de Janeiro: Lúmen Júris, 2003.

STOCO, Rui. Tratado de Responsabilidade Civil: doutrina e jurisprudência. 7. ed. São Paulo: Revista dos Tribunais, 2007.

TEIXEIRA, Ana Carolina Brochado; RETTORE, Anna Cristina de Carvalho. Os reflexos do conceito de família extensa no direito de convivência e no direito de visitas. Civilistica.com. Rio de Janeiro, a. 6, n. 2, 2017. Disponível em: < http://civilistica.com/os-reflexos-do-conceito-de-familiaextensa> Acesso em 15 de setembro de 2018.

VENOSA, Sílvio de Salvo. Direito Civil - Responsabilidade Civil. 7 ed. São Paulo: Atlas, 2007. 